\title{
Is Role of WTO Shrinking?
}

\section{Iqbal $\mathrm{BA}^{1,2,3 *}$}

${ }^{1}$ Collage of Business Administration, International University of Business, Agriculture and Technology, Dhaka, Bangladesh

${ }^{2}$ School of Economics and Finance, Monarch University, Zug, Switzerland

${ }^{3}$ Department of Commerce, Aligarh Muslim University, ALIGARH, UP, India

\section{Introduction}

It is an undisputed fact that developed nations must realize that the global trade issues could not be solved without taking into confidence and framework the emerging economies in general and China and India in particular. The situation has been changed considerable in case of China and India since the declaration of Doha negotiations as back 2001. The developed nations and developing nations must adopt the balanced policy of give and take [1].

The transformation of General Agreement on Tariffs and Trade (GATT) of 1947 into World Trade Organization (WTO) on January 1, 1995 was considered a mile stone in the history of world trade. The very purpose of creating WTO was to promote and stimulate multilateral trading system and minimization of regionalism. After the deadlock at Doha Development Round in 2001, there has been enormous increase in Free Trade Agreements (FTAs) which means we are going back to the concept of regionalism which is against the philosophy of multilateral trading system in general and the existence of WTO in particular.

World trade continues its slow recover but with economic growth still fragile and continued geopolitical tensions, mainly because of the sluggish economic growth [2]. The WTO data is based on economic growth estimates from organization including the IMF. The new IMF figures and these would be 'in the same ballpark' and not affect WTO's projection. Although the projections do opined some modest growth in the in the global goods, they follow repeated down ward revisions of trade estimates as the economic outlook worsened [3].

Global trade registered a rise of $2.4 \%$ in 2014 , much less than an original projection of $4.7 \%$ and also below the revised projection of $3.1 \%$. The new projection of $3.3 \%$ growth in 2015 ; already revised down twice, from $5.3 \%$ and then $4 \%$, is meager increase but much less than the long term trend. World trade growth averaged $2.4 \%$ over each of the last three years, compared with an annual average of 6\% during 1990 and 2008 when global financial crisis was occurred. There has been only other period since the Second World War wherein world trade growth had been so weak and that was from 1980 to 1984 [4]. However, that period included two most strategic contractions in global trade because of the oil shock and the world recession witnessed during 198-81.

\section{Trade Blocks}

Although G-20 countries are eliminating some of their respective trade-restrictive measures, the pace at which this is being done remains slow. Hence, the overall stockpile up of measures continues to grow. Of the total 1,441 trade restrictive measures, including trade remedies, introduced since 2008, only 354 had been removed (Table 1). In the year 2010, out of 381 effectively eliminated measures, only 57 or $15 \%$ were possible and 324 measures remained un eliminated. In 2015, 354 or $24.6 \%$ were stockpile up restrictive measures out of 1,441 stockpiles up restrictive measures. Hence, this is one of the issues of great concern for WTO members' countries (Figure 1).

\section{Emerging trends in global exports, imports and balance of trade}

Recently, the WTO has revised its 2016 world trade projections with a margin of one percentage point. In last September the WTO had forecasted that world trade would witness by $3.9 \%$. But unfortunately, the figure was revised to $2.8 \%$. This is because of the slowdown in Chinese economy along with the broad market volatility in the global economy. In the words of the Director General of WTO, "trade is till registering positive growth, albeit a disappointing rate" [5].

\begin{tabular}{|c|c|c|}
\hline Year & Restrictive measures & Facilitating measures \\
\hline 2009 & 19 & 13 \\
\hline 2010 & 14 & 16 \\
\hline 2011 & 18 & 17 \\
\hline 2012 & 17 & 18 \\
\hline 2013 & 18 & 16 \\
\hline 2014 & 19 & 17 \\
\hline May-October 14 & 19 & 16 \\
\hline October 14-May 2015 & 17 & 16 \\
\hline May-October 2015 & 17 & 12 \\
\hline \multicolumn{3}{|c|}{ Source: WTO, Geneva, 2015.} \\
\hline
\end{tabular}

Table 1: G-20 trade measures average per month.

\section{G-20 Trade Measures Average per month}

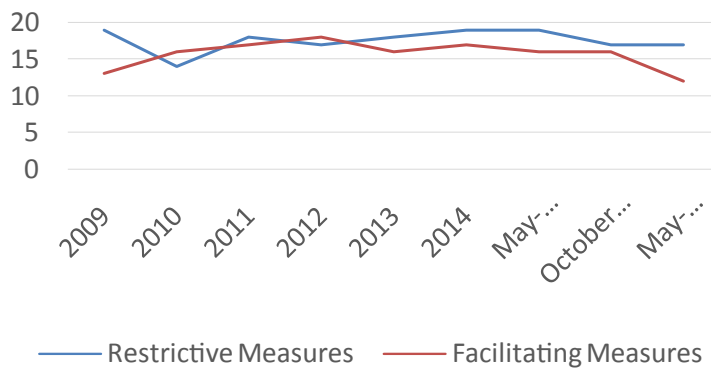

Source: Prepared by the author from Table 1.

Figure 1: G-20 Trade Measures Average per month.

*Corresponding author: lqbal BA, School of Economics and Finance, Monarch University, Zug, Switzerland, Tel: 00414178008 82; E-mail: dr.iqbal@monarch-university.ch

Received May 27, 2016; Accepted June 16, 2016; Published June 23, 2016

Citation: Iqbal BA (2016) Is Role of WTO Shrinking? Bus Eco J 7: 219 doi:10.4172/2151-6219.1000219

Copyright: (c) 2016 Iqbal BA. This is an open-access article distributed under the terms of the Creative Commons Attribution License, which permits unrestricted use, distribution, and reproduction in any medium, provided the original author and source are credited. 
Global merchandise trade volume is estimated to increase by 2016 , unchanged from 2.8\% in the year 2015, as Gross Domestic Product (GDP) eases out in developed countries and also picks up in developing economies. Global trade should increase by a margin of $3.6 \%$ in coming year 2017, still lesser the average of 5\% recorded since 1990 . These trends are attributed to downside, including slowing trends in emerging economies and their respective financial volatility especially in China and India.

Exports of developed countries lagged behind developing economies in 2015 , with a figure of $2.6 \%$ volume growth in regard to developed nations and $3.3 \%$ in case of developing economies (Table 2).

Table 2 gives some very interesting trends and situation. First, the global exports increased marginally and the lowest witnessed the lowest growth rate. Secondly, China has registered the highest increase in its exports at a figure of $6 \%$ many times higher than the global exports growth in exports. Thirdly, Germany recorded witnessed a positive change of $3.4 \%$ much higher than change in the exports of USA and India [6]. This all indicates that China was the best performer followed by Germany, USA and India in terms of annual positive change in their respective exports.

Developed countries imports registered increase last year whereas developing economies remained stagnant, with growth rate of $4.5 \%$ in case of developed nations and marginally $0.2 \%$ in case of developing countries. An appreciable trade slowdown affected all countries and regions in Quarter 2 of 2015 (Table 3).

Table 3 reveals that except India, other economies namely had witnessed a rise in the imports and the increase was highest in case of USA followed by Germany and the China in the year 2014 [7]. But in 2015 the annual change in the world imports was negative and the largest annual change was recorded in case of India followed by China, Germany and world. The lowest negative growth was recorded in case of USA. South America witnessed the weakest import growth in 2015 as a severe recession in Brazil depressed demand (Figure 2).

If we compare the date of Tables 2 and 3 namely global exports and world imports, and exports and imports of selected major economies of the world, it is clear that global trade has negative balance of trade along with India and the USA (Figure 3). On the other hand, balance of trade is positive in case of China and Germany. The highest balance of

\begin{tabular}{|c|c|c|c|}
\hline Country/World & $\begin{array}{l}\text { Value in } 2015 \text { in } \\
\text { (US \$ Billions) }\end{array}$ & $\begin{array}{c}\text { Annual \% Change } \\
\text { in } 2014\end{array}$ & $\begin{array}{c}\text { Annual \% change } \\
\text { in } 2015\end{array}$ \\
\hline World & 15,985 & 0.3 & -13.5 \\
\hline India & 267 & 2.5 & 17.2 \\
\hline China & 2,275 & 6.0 & -2.9 \\
\hline USA & 1,505 & 2.6 & -7.1 \\
\hline Germany & 1.329 & 3.4 & -11.0 \\
\hline
\end{tabular}

Table 2: Emerging trends in global exports in 2015.

\begin{tabular}{|c|c|c|c|}
\hline Country/World & $\begin{array}{l}\text { Value in } 2015 \text { in } \\
\text { (US \$ Billions) }\end{array}$ & $\begin{array}{c}\text { Annual \% Change } \\
\text { in } 2014\end{array}$ & $\begin{array}{c}\text { Annual \% change } \\
\text { in } 2015\end{array}$ \\
\hline World & 16,340 & 0.7 & -12.4 \\
\hline India & 392 & -0.5 & -15.3 \\
\hline China & 1,682 & 0.5 & -14.2 \\
\hline USA & 2,308 & 3.6 & -4.3 \\
\hline Germany & 1.050 & 2.2 & -13.0 \\
\hline
\end{tabular}

Table 3: Emerging trends in Global Imports in 2015.
Changes in Annual Growth Rate (\%)

20

0

$-20$

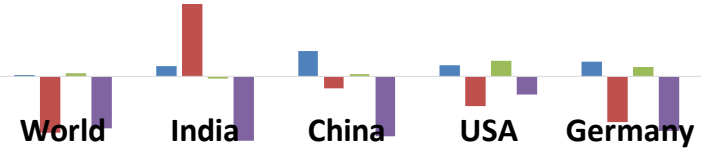

Exports (2014) $\square$ Exports (2015)
Imports (2014) $\square$ Imports (2015)

Source: Prepared by the author from Tables 2-4.

Figure 2: Changes in Annual Growth Rate (\%).

Emerging trends in Global Exports, Imports \& Trade Baalnce in 2015 (US\$ Billions)

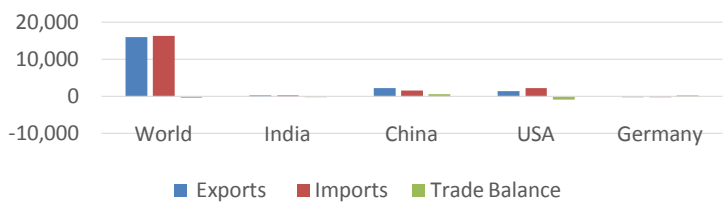

Source: Prepared by the author from Tables 2-4.

Figure 3: Emerging trends in Global Exports, Imports and Trade Balance in 2015 (US\$ Billions)

\begin{tabular}{|c|c|c|c|}
\hline Country/World & $\begin{array}{c}\text { Value of Exports } \\
\text { in 2015 in } \\
\text { (US \$ Billions) }\end{array}$ & $\begin{array}{c}\text { Value of Imports } \\
\text { in 2015 in } \\
\text { (US \$ Billions) }\end{array}$ & $\begin{array}{c}\text { Value of Balance } \\
\text { of Trade in 2015 } \\
\text { in (US \$ Billions) }\end{array}$ \\
\hline World & 15,985 & 16,340 & -355 \\
\hline India & 267 & 392 & -25 \\
\hline China & 2,275 & 1,682 & +593 \\
\hline USA & 1,505 & 2,308 & -807 \\
\hline Germany & 1.329 & 1.050 & +279 \\
\hline
\end{tabular}

Table 4: Emerging trends in global balance of trade in 2015.

trade is in regard to China and the largest trade deficit is in case of USA during the year 2015 [8] (Table 4).

\section{Persisting Failures}

It is a well known fact that the developed countries had already expressed their desire to close down the excruciating and inconclusive 14 year old Doha Development Round (DDR). The Cancun ministerial collapsed when the African group walked out of the green room on Singapore issues namely- investment, competition, transparency in Government procurement and trade facilitations. Out of four at Singapore issues, trade facilitation was retained and wrapped up for the Bali Ministerial conference in 2013. With the Nairobi Declaration explicitly indicating that there is no consensus on continuation of Doha Development Agenda (DDA/DDR) the stage is set for the introduction of new issues which means new battle fronts for developing and least developing economies [9].

\section{$10^{\text {th }}$ Summit at nairobi}

At the time of $10^{\text {th }}$ Ministerial Conference/summit at Nairobi convened by the World Trade Organization (WTO), the most strategic 
issue which has far reaching impact, consequences and implications on the very future of the WTO. World trade community was of the view that the role and contribution of WTO is in doldrums. 160 member nations are facing a serious existential crisis. This is because since the inception of WTO on January 1, 1995, the WTO has failed to fulfill its objectives and functions for which it was established. WTO has only one silver lining i.e. Trade Facilitations Agreement (FTA) of 2013 [10].

The persisting existential crisis with which the WTO confronting with has become more delicate because of the rapid rise in the FTAs especially the latest one Trans Pacific Trade Agreement which is against the philosophy of WTO whose very basic principle is Most Favored Nation (MFN). The Nairobi summit concluded with disappointment as the United States has opposed the revival of Doha Development Round (DDR). The developing countries in one voice attempted to hold on strongly to their ground by refusing to allow a pact that does not fall in line with the DDR. The developing economies stayed away from a deal on 'export competition' for removing export subsidies and farm subsidies [11].

The United States of America was very adamant and had not want to reaffirmation of DDR in Nairobi (Kenya) declaration, the developing economies in general and India and China in particular were trying hard to argue that non-revival of DDR would be a breach of faith and confidence in regard to developing economies in general and least developing countries in particular who have been waiting for developed nations to deliver the commitment of market access and preferences that were promised when DDR was initiated i.e. as back 2001.

The continuation of DDR is sine-quo-non for developing countries in general and least developing nations in particular as it contain the most essential provision of "less than full reciprocity". This clause keeps much onus on developed economies especially the USA and European Union to provide deeper market access and other vital trade concessions to developing economies and least developing economies as against to what they get in return.

Nairobi and thereafter, the negotiations on a number of areas comprising of market access to industrial goods and agricultural products and reduction in farm subsidies which are based on the less than full reciprocity rue that make least developing economies net gainers. On the other side of it, the USA is trying hard to introduce new issues namely-investment, competition policy and government procurement once it achieves the official declaration of burying DDR [12].

The most conspicuous segment in Nairobi Declaration is the implicit recognition of the fact that many countries have started to show less interest in the DDDR/DDA of 2001 work programme. The usual and strong affirmation of commitment to the work programme, shown even as late as 2013 at Bali conference; is muted in the Nairobi ministerial declaration. It is pertinent to point out here that in paragraph 30 of Nairobi declaration it is opined that many member countries reaffirm the DDA while others have not as the countries are of the view that new approaches have become essential to attain purposeful and meaningful outcomes. It is further opined in paragraph 34 that "while we concur that officials should prioritise work wherein results have not yet been attained, some wish to identify and discuss other issues for negotiations; others do not". This is true that introduction of initiation of other issues will be subject to the agreement of all members [13].

It is certain and appeared that the negotiations after the completion of $10^{\text {th }}$ Summit at Nairobi would not be confined to the broad framework of the Doha work programme as it has evolved over the last decade and a half. Newly emerging issues will be put on the negotiation table and issues which have been discussed and removed or modified during negotiations after DDR may reappear on the table. The long drawn out DDA/DDR negotiations, yet to see significant result in key strategic areas, and the proliferation of bilateral and regional trading arrangements have led to decline interest in the WTO work.

\section{Major out come of summit}

a) Failed to deliver anything concrete in the areas of food security and farmers protection;

b) Doing away with all export subsidies in the coming eight years;

c) No definite agreement reached in case of Special Safeguards Mechanism (SSM) for giving protection to famers in developing countries and least developing nations;

d) The SSM negotiations will take place in the older format (Hong Kong Summit)

As many as 53 WTO member nations has agreed in Nairobi to a "Seven-Year" time frame to remove all tariffs on 201 IT goods that constitute annual trade amounted to US\$ 1.3 trillion. India did oppose such an agreement on the grounds that the deal would be beneficial to the USA, China, Japan and Korea who have a robust manufacturing base in the above mentioned goods.

\section{Role of China and India}

The two emerging and fastest growing economies of the world would continue to fight for the revival of DDR/DDA. On public stock holding where emerging economies looking for a permanent solution for the treatment of subsidies regime so that these could not attract penalties [14]. China and India has come out together with the intention that these emerging economies jointly pursue the issue with greater vigour in Geneva so that an effective work program could be given at the earliest and should be based on the special sessions of the Committee on agriculture must be held.

\section{Rethinking on WTO}

It is an undisputed fact that WTO is the only multilateral forum wherein smaller and developing countries always made out the concerted efforts in respect to the integration of trade with development. The multilateral agency (WTO) permits the developing and least developing economies to deliberate and negotiate global trade issues in blocks and together withstand the relentless demand of the developed world to open the markets for them without the reciprocity so that every nation could reap out the benefits of trade [13].

Prolong deadlock in regard to Doha Development Round (DDR) of 2001, there is a major rethink of the WTO's tariff reducing regime which is in place. This may be called tariff liberalization approach. Accordingly, trade economists are preparing the agenda and negotiating priorities in place of actual trade policy negotiations.

In the absence of global cooperation, governments of the member countries are imposing import tariffs which mean imposing economic costs on trading partners. The tariff takes down the price that the trading partners' exporters get for selling out their products in the global markets. The cost arise due to the fact that importer has possessed market power [13].

The biggest disappointment is that the Nairobi ministerial declaration is virtually brings to an end the co called consensus on the 
DDR/DDA. But this is not loss to any country but is for all developing and least developing economies. As a matter of fact, DDR/DDA is the very first round was very first and most critical and strategic round of trade negotiations launched by the WTO. If that round cannot be completed as originally intended, the loss is that of the WTO as a whole.

\section{Trade facilitation agreement (FTA)}

Trade Facilitation Agreement (TFA) has come for easing out the customs procedures to enhance commerce among the member countries in particular and other non-member countries in general. The main constraints standing in the way of its implementation is that 107 member countries or $2 / 3^{\text {rd }}$ of the total members have to approve it.

The very purpose of FTA was to expedite the movement i.e. release and clearance of goods including products that are in transit for the promotion of global trade. The other objective of FTA was to lay down measures required for effective and efficient cooperation among customs and other concerned officials for trade facilitation on the one hand and on the other hand dealing with customs compliance issues.

In the words of WTO, full implementation of FTA may enhance the world exports to the extent of US\$ 1 trillion annually which will enormous rise. Accordingly, the global exports may rise by a margin of $2.7 \%$ per annum. Trade facilitation does require the harmonization in the existing relationship among essential departments namely-custom, shipping and ports, road transport and highways along with other institutional authorities of the concerned country [14].

Developing economies exports projected to rise by a margin of between US\$ 170 billion and US\$ 730 billion in a year. Fuller and faster implementation of the FTAs could enhance the likelihood of impacts reaching the larger ends of these ranges. According to the Dynamic Computable General Equilibrium Model, the increases of world exports are estimated at a figure range of US\$ 1.8 trillion and US\$ 3.6 trillion.

Economically, FTAs are acting upon as creating blocks for multilateral trading regime, and if they liberalise for substantially all trade among the constituents and may not impose a higher burden on non-constituent members that what existed earlier the formation of the free trade zone. These provisions are given in the Article XXIV of the GATT which is an integral part of the WTO and constituent an exception to the MFN rule. Hence, all FTAs that WTO member nations sign have to satisfy these legal requirements. Therefore, the only way to keep WTO relevant is by making concerted efforts for strengthening its existing mechanisms that exercise supervisory control over FTAs.

\section{WTO and India}

In the present scenario, of multilateral, plurilateral as well as bilateral world, trade deliberations and negotiations are always insist upon the principle some give some take as and are not based on winning or losing. Hence, trade deliberations and negotiations have become more delicate in nature and contents [12].

India must come out with a balanced approach in negotiating the trade issues. India should strongly take up the most burning issues namely- food security and farmers protection. India has refused to be a party to the WTO's trade facilitation agreement last year with a logical rider that till a permanent solution for its food security issue is found. India has come out with a new approach that is fall in line with its efforts to play a greater role in the global trade affairs [13]

It is very true that India did not get everything that the country wanted in upcoming trade negotiations. Trade experts are of the view that India should adopt a policy and carry out it in such a way that India is seen neither a blocking a pact nor seen as diluting its stand.

According to trade experts, the Ministerial negotiations have happened in African continent for the first time in the WTO history, Kenya was under pressure to make the negotiations successful. Hence, it was considered most important for India which is seen as a Africa's natural partner to push the food security issue sine-quo-non for developing countries in general and African economies in particular [7].

India and Africa also wanted that the DDR/DDA must be revived keeping in mind the threat arising out from the mega trade agreement namely Trans-Pacific Partnership (TPP) which is taken place among 12 Pacific Rim nations; and Regional Comprehensive Economic Partnership (RCEP), a proposed FTA taken place among ASEAN and six other Asia Pacific nations including India.

And as was committed in Bali and also as was reaffirmed in Nairobi, a permanent solution to the food security should emerge out in 2017 when next ministerial negations will be held. On the critical of special safe guard mechanism to protect farmers against any spurt in imports and volatility in commodity prices, the Indian Government has made sure that what was given to us as a right in Hong Kong ministerial declaration must be honoured. Now a decision to commit on the SSM and a decision to agree upon a work plan on the SSM is made out at Nairobi, the work plan must come out with clarity [12].

India and other developing economies have been successful in keeping away any provision to allow ever greening of patents at the Nairobi ministerial of WTO despite much pressure from some nations to contrary. The firm stand was aiming at ensuring accessibility and affordability of generic medicines.

It is imperative to mention here that there is much difference in regard to India's position in 2001, when Doha declaration was issued and the India 2016 when Nairobi declaration was issued. This is because India has evolved and progressed in various aspects and India's interest has also been changed with time.

India and Other developing nations have been successful in preventing any provision to allow "ever greening" of patents at the Nairobi, despite the very fact that there has been much pressure from developed countries. This firm stand did aim to ensure accessibility and affordability of generic medicines.

\section{Services negotiations}

India is seeking trade facilitation pact for services at WTO negotiations. This is because India enjoys considerable competitiveness in the services. There is a need to have a trade facilitation agreement for services on the lines of agreement for goods. It is believed that India will raise this issue when developed economies press upon the introduction of new issues. The elimination of barriers to services export and seamless movement of services is what the need of the hour is [14].

\section{Newly emerging challenge}

The developing world could face difficulties in facing trade disputed at WTO in coming years. This is because the world trade slows, may result into much higher level of protectionism world over and that is what the developing economies are witnessing. As a result, there could be an increase use of trade remedies and these are used often, hence, some of these may come up as trade disputes [8].

The developing countries are facing paucity of legal professionals 
to deal with an increasing case of trade disputes. These cases could pose a great challenge in the coming times for developing economies due to the fact that very often these are conditions that may add as restrictions in the free movement of trade and servicers.

The biggest challenge is to deal with labour and environment issue wherein developing economies are at disadvantageous position. For instance, India has been very active in regard to WTO's dispute settlement mechanism. India is a complainant in 22 cases and also respondents in 23 cases as well as third party in nearly 100 cases. India and other developing nations have to increase the "pool" of trade lawyers and legal experts to handle disputes case in most effective and efficient manner. What is of most concern is that India and other developing countries have very limited lawfirms. The number of such firms must grow as it is the only available option.

\section{What should be done?}

The real fact is that DDA/DDR is dead and accordingly, there is no point in wasting time and energy to put DDR/DRA back on track. This does not mean the WTO is become irrelevant. There are different segments of the multilateral trading system that have contributed significantly in protecting the interest of developing and least developing economies. These countries must work for preserving these aspects at all costs. India and other developing countries along with least developing economies must seek a discussion on the survival of multilateral trading system and strengthening the WTO to make it more relevant in upcoming G-20 Summit in China in 2016. It is true to say that China owes it to all developing and least developing countries to make best use of its presidency of the G-20 for getting world commitment on the strengthening the existing multilateral trading system. A proactive role, in keeping with the present political and economic interest could serve the interest of developing economies in general and least developing economies in particular. A comprehensive conclusion of the DDR/DDA with economically meaningful and balanced outcomes could provide impetus to world trade liberalization and facilitation.

\section{References}

1. Baru S (2015) The big deal about WTO: India got some and gave some at Nairobi. The Economic Times. New Delhi.

2. Bown CP (2015) Emerging economies and WTO tariff liberalisation after Doha The Financial Express New Delhi.

3. Chandrasekhar KM (2016) Think Again at WTO. The Indian Express, New Delhi.

4. Mehta P (2016) The Road after Nairobi Ministerial. The Business Line, Chennai

5. Ranjan P, Ranjan R (2015) Saving the WTO from the Risk of Irrelevance. The Business Standard, New Delhi.

6. Srivastava S (2016) India to seek Trade Facilitation Pact for Services at WTO. The Indian Express, New Delhi.

7. The Business Line (2015) India, China Will continue to Fight for the Doha Agenda. Chennai.

8. The Economic Times (2015) TFA: A Trillion Dollar Gain. New Delhi.

9. Finance every day (2015) India to Adopt Balanced Approach at WTO Meet New Delhi.

10. The Economic Times (2015) Trade Blocks. New Delhi.

11. The Financial Express (2015) WTO Cuts Trade Growth Forecasts for 20152016. New Delhi.

12. The Financial Express (2015) India to Pursue Food Security Issue at WTO New Delhi.

13. The Indian Express (2016) WTO Cuts 2016 Global Trade Forecast to $2.8 \%$ New Delhi.

14. The Indian Express (2016) Need to develop Legal Capacity. New Delhi. 